\title{
NEW STAGE OF THE INVASION: SPOROBOLUS VAGINIFLORUS (POACEAE) REACHED HUNGARY
}

\author{
Gergely KIRÁLY ${ }^{1 *}$ and Michael HoH LA ${ }^{2}$ \\ ${ }^{1}$ Institute of Silviculture and Forest protection, University of West Hungary, \\ H-9400Sopron, Ady E.u. 5, Hungary; *kiraly.gergely@emk.nyme.hu \\ ${ }^{2}$ Therese-Riggle-Straße 16, A-4982 Obernberg am Inn, Austria
}

Király, G. \& Hohla, M. (2015): New stage of the invasion: Sporobolus vaginiflorus (Poaceae) reached Hungary. - Studia bot. hung. 46(2): 149-155.

\begin{abstract}
Sporobolus vaginiflorus, a "for a long time expected" invasive alien of North American origin has now reached Hungary. The first stands were recorded in 2015 in SW Hungary on the motorway M70 near Letenye; its occurrence was already foreseen in view of its expansion along the roads of Croatia and Slovenia. Similarly to other aliens (e.g. Senecio inaequidens, Plantago coronopus) arriving from the Adriatic direction on the newly constructed motorways the authors reckon with its further rapid expansion in Hungary.
\end{abstract}

Key words: alien species, highways, invasion, salt-tolerant plants

\section{INTRODUCTION}

Transportation corridors play an important role in recent days' biological invasions (e.g. HANSEN and Clevenger 2005, KAlwiJ et al. 2008, ŠERÁ 2008, KOWARIK and VON DER LIPPE 2011). Numerous well-documented Central European invasions of ruderal plant species were connected to highways; see the examples of Dittrichia graveolens (Frajman and KALIGARIČ 2009, RAABE in HAdinec and Lusty K 2009, STÖHR et al. 2009) or Plantago coronopus (GerstBERGER 2001, HoHLA 2012). On the other side, the railway lines and stations seem to be losing of their importance in plant invasion; the last spectacular railway-expansions recorded in Central Europe (e.g. Geranium purpureum: HÜGIN et al. 1995, WALter 1998, Eliáš 2011; Senecio inaequidens: ERnST 1998, DANCZA and KirÁLY 2000, BORNKAMM 2002) could mainly be dated to the $1990^{\text {s. }}$.

Sporobolus is a nearly cosmopolitan genus of more than 160 species, with only two species native to Europe; several other representatives of the genus have been recognised as aliens (HANSEN 1980, PETERSON et al. 2010). In recent study we report on the first record of the long-awaited thermophilous annual species Sporobolus vaginiflorus (Torr.) Wood. from Hungary. Beside the brief description 
of the invasion history of this taxon in Central Europe we also discuss its possible role in the Hungarian habitats.

\section{MATERIAL AND METHODS}

The field study was conducted in autumn 2013 and 2015. The coordinates of the recorded localities were determined using a Garmin GPSMAP 64 device. Quadrant number is given according to the Central European Flora Mapping System (NIKLFELD 1971). Herbarium acronyms used in the text follow THIERS (2015). The topographical classification of Hungary is considered according to DövÉNYI (2010). The specimens of Sporobolus vaginiflorus were identified using the keys of MELZER (2003) and FisCHER et al. (2008).

Nomenclature of plant names follows KIrÁLY (2009).

\section{RESULTS AND DISCUSSION}

The grass genus Sporobolus involves two species native to the Mediterranean territories in Europe (ALEgRo et al. 2003). From the several other exotic species found later on the continent, only two annuals, $S$. neglectus Nash and $S$. vaginiflorus became invasive in Central Europe. The genus is already known from Hungary: in the early 1900s three taxa (S. argutus Kunth, S. elongatus R. Br. and S. subinclusus Phil.) were reported as casuals in the industrial zone of the NW Hungarian city of Győr (POLGÁR 1941).

Sporobolus vaginiflorus is an unimpressive, morphologically variable species native to North America (Peterson et al. 2007, HARMs 2015). It is distinguishable from the only similar representative of the genus ( $S$. neglectus) in Europe by the strigose lemmas ( $S$. neglectus: glabrous), by spikelets (2.5-)3.0-6.0 mm long (S. neglectus: $1.5-3.0 \mathrm{~mm}$ ), and by mature fruits longer than $1.8 \mathrm{~mm}$ (S. neglectus: $1.2-1.8 \mathrm{~mm})$. The top of the inflorescence is often overhung by the sheet of the uppermost leaf (in the case of $S$. neglectus it is regularly shorter than the inflorescence), but this feature is only observable on fruiting specimens (Fig. 1).

Sporobolus vaginiflorus was firstly reported from Europe in 1951 (NE Italy: Gorizia), and, due to its rather unnoticed expansion it later reached Croatia (1959), Slovenia (1963) and France (1987) (Wilmalm 1998). In Switzerland it is known since 1997, in Austria since 2001; in both countries it is still in expansion (Melzer 2003, Tinner 2013). The species was recently recorded in Montenegro (STEŠEviĆ and Jogan 2006) and in Bavaria, Germany (Nawrath in FÜrnROHR 2015) as well.

The nearest published occurrences of S. vaginiflorus to Hungary are situated in Southern Carinthia (Melzer 2003), Central Croatia (Horvatić and 
Gospodarić 1960), and Central Slovenia (Jogan 2001). The species was observed also by G. Király along A4 motorway (E65) in Croatia near Donji Hrašćan (2013, only $4 \mathrm{~km}$ away from the Goričan-Letenye border station), and along A5 motorway in Slovenia near Lormanje (2015) abundantly. Thus, it was also expected that this species is already present in Hungary. Nevertheless, a search for the species on the connected sections at some motorway stations of the Hungarian roads M70 and M7 in 2013 was not successful. In order to clarify its occurrence in Hungary, in 2015 we systematically searched through both highways from Tornyiszentmiklós to Letenye (M70), and from Letenye to Balatonkeresztúr (M7), respectively, and we recorded its occurrence at the following localities:

Hungary, Zala County, Letenye, $0.6-0.9 \mathrm{~km}$ NE of Goričan-Letenye highway border station along the southern lane of the motorway M70 near the junction M7/M70, two approx. $20 \mathrm{~m}$ long homogeneous stands on the medial strip of the motorway, $46.41656^{\circ} \mathrm{N}, 16.71949^{\circ} \mathrm{E}$ and $46.41494^{\circ} \mathrm{N}$, $16.72537^{\circ}$ E, 139 m, 9566/3; leg. G. Király and M. Hohla, 26.09.2015, BP, LI and herb. Király (Fig. 2).

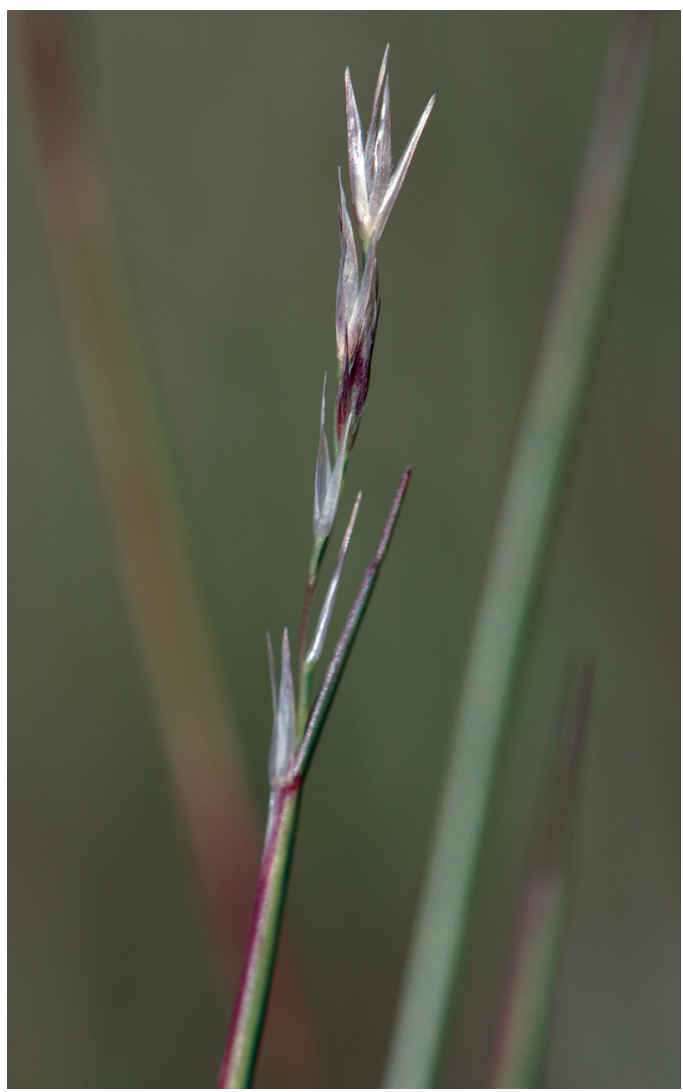

Fig. 1. Sporobolus vaginiflorus: inflorescence of a mature specimen (photo: M. Hohla, Upper Austria, 2015). 


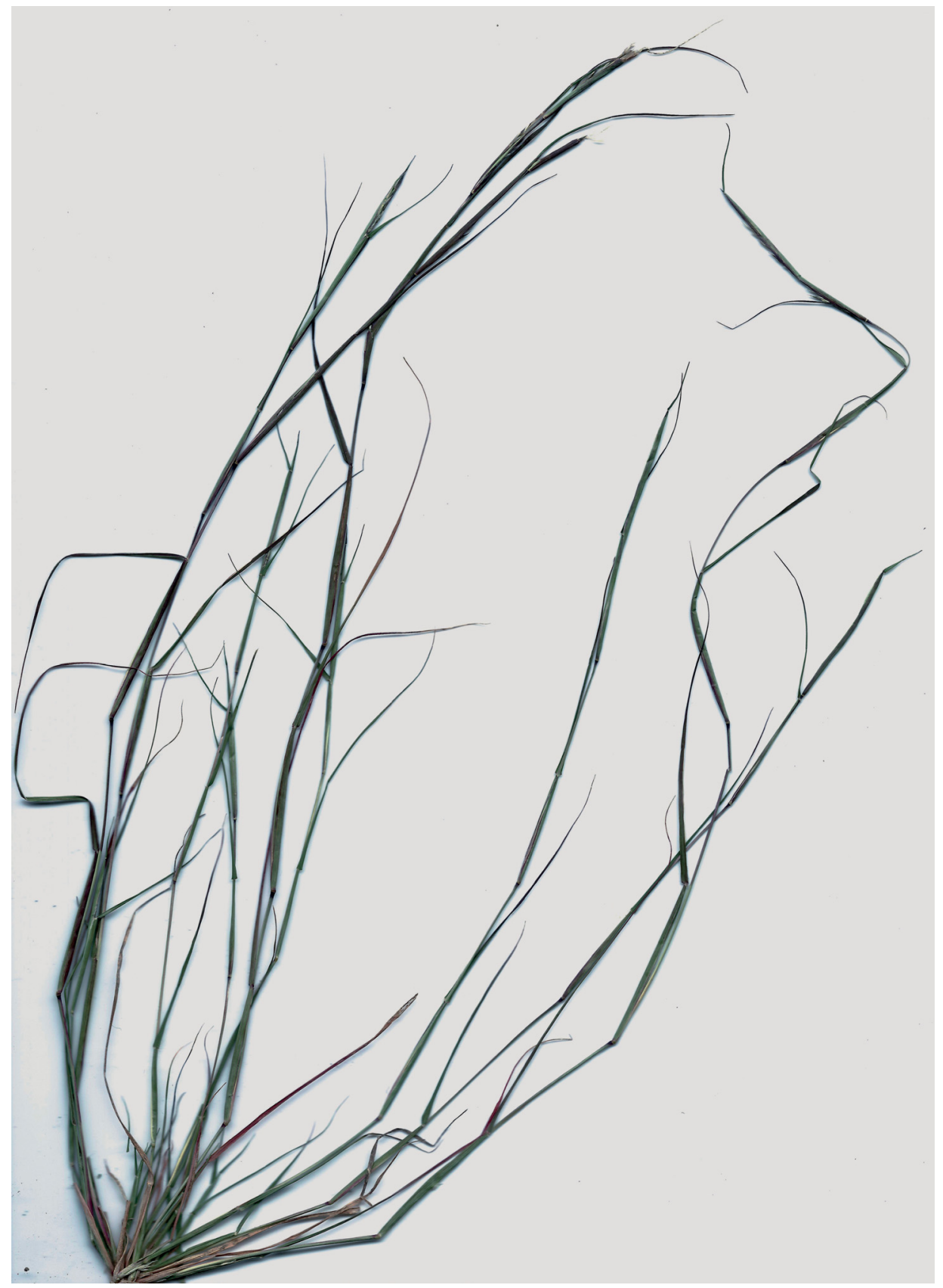

Fig. 2. Sporobolus vaginiflorus: habitus of a voucher specimen from Hungary (photo: M. Hohla, Letenye, 2015, LI). 
The speed of its expansion in the region is not really known because the stages of the spread from the Adriatic Sea to the Pannonian Basin are barely documented. In Slovenia Jogan (2001) reported its presence still only from the Ljubljana-region, thus we consider here (in spite of data deficiency) a specifically rapid (more $10 \mathrm{~km} /$ year) advancement. As it was observed along the motorway M70, it likely reached the Hungarian territory from the "Slovenian" direction; but on the "Croatian" line, namely the highway M7, it is also highly expected.

Sporobolus vaginiflorus has approximately $0.5 \mathrm{~m}$ broad homogeneous stands on both new sublocalities in Hungary, near Letenye. The species-pool noticed here on the medial strip of the highway is as follows: Atriplex patula, Bothriochloa ischaemum, Cichorium intybus, Elymus repens, Eragrostis pilosa, Polygonum aviculare s. 1., Puccinellia distans, Tragus racemosus, Thrincia nudicaulis. This salt-tolerant species composition (excluding Sporobolus) is typical and widespread along the regularly cut highway-margins of SW Hungary. Phytocoenological studies of Sporobolus vaginiflorus stands in Central Europe are not yet published, but we believe that it grows along the highways in neighbouring countries in similar situations as in Hungary. Nature conservational threats caused by $S$. vaginiflorus in the region have not yet been reported; we also do not calculate with its expansion (similarly to the case of other invaders in ruderal plant communities, such as Plantago coronopus and Senecio inaequidens) in natural habitats in Hungary.

Acknowledgements - The study of Gergely Király was supported by the project "Agrárklíma.2 VKSZ-12-1-2013-0034".

Összefoglaló: A Sporobolus (Poaceae) nemzetség számos faja közül Európában kettő őshonos, további két amerikai taxon pedig özönnövény. Utóbbiak egyike (S. vaginiflorus) több szomszédos országból (Ausztria, Horvátország, Szlovénia) előkerült már, gyors terjedése elsősorban autópályák mentén figyelhető meg. Mivel délnyugati irányból az elmúlt években megközelítette az országhatárt, hazai előfordulása is várható volt, amelyet szisztematikus kereséssel 2015 őszén sikerült is megerősíteni Letenye térségében (Zala megye). A faj itt az M70 autópálya középső sávján monodomináns foltokat alkotva, rendszeresen nyírt sótűrő ruderális növényzetben fordul elö. Továbbterjedése az M7 autópálya mellett bizonyára csak idő kérdése, de természetvédelmi problémákat (hasonlóan pl. a szintén gyorsan terjedő Plantago coronopus és Senecio inaequidens hazai viselkedéséhez) várhatóan nem okoz nálunk.

\section{REFERENCES}

Alegro, A. L., Biljaković, M., Bogdanović, S. and Boršić, I. (2003): Sporobolus pungens (Schreber) Kunth (Poaceae), rare and endangered psammophytic plant species in Croatia. Natura Croatica 12: 1-7.

BORNKAMM, R. (2002): On the phytosociological affiliations of an invasive species Senecio inaequidens in Berlin. - Preslia 74: 395-407. 
DANCZA, I. and KirÁLY, G. (2000): A Senecio inaequidens DC. előfordulása Magyarországon. [The occurrence of Senecio inaequidens DC. in Hungary]. - Kitaibelia 5: 93-109.

DövÉNYI, Z. (ed.) (2010): Magyarország kistájainak katasztere. [Cadastre of small regions of Hungary]. - Budapest, MTA Földrajztudományi Kutatóintézet, 876 pp.

ELIÁš, P. jun. (2011): Geranium purpureum Vill. - new alien species to the Slovak flora. - Thaiszia 21: 21-28.

ERNST, W. H. O. (1998): Invasion, dispersal and ecology of the South African neophyte Senecio inaequidens in the Netherlands: From wool alien to railway and road alien. - Acta Bot. Neerl. 47: 131-151.

FISCHER, M. A., ADLER, W. and OsWALD, K. (2008): Exkursionsflora für Österreich, Liechtenstein und Südtirol. 3., verbesserte und erweiterte Auflage. - Land Oberösterreich, OÖ Landesmuseen, Linz, 1392 pp.

Frajman, B. and Kaligarič, N. (2009): Dittrichia graveolens, nova tu je rodna vrsta slovenske flore. [Dittrichia graveolens, a new species to the Slovenian flora]. - Hladnikia 24: 35-43.

FürnRohr, F. (ed.) (2015): Bemerkenswerte Pflanzenfunde im Regnitzgebiet seit 2002. - RegnitzFlora 7: 72-76.

Gerstberger, P. (2001): Plantago coronopus subsp. commutata als Straßenrandhalophyt eingebürgert in Mitteleuropa. - Tuexenia 21: 249-256.

HAdinec, J. and Lustyk, P. (eds.) (2009): Additamenta ad floram Reipublicae Bohemicae VIII. Zprávy České botanické společnosti 44: 185-319.

Hansen, A. (1980): Sporobolus R. Br. - In: Tutin, T. G., Heywood, V. H., Burges, N. A., Moore, D. M., Valentine, D. H., Walters, S. M. and Webb, D. A. (eds): Flora Europaea. Vol. 5. Cambridge University Press, Cambridge, pp. 257-258.

Hansen, M. J. and Clevenger, A. P. (2005): The influence of disturbance and habitat on the presence of non-native plant species along transport corridors. - Biol. Conservation 125: 249-259. http://dx.doi.org/10.1016/j.biocon.2005.03.024

Harms, R. T. (2015): A survey of the Sporobolus compositus and Sporobolus vaginiflorus complexes (Poaceae) in Texas. - Phytoneuron 49: 1-27.

HoH LA, M. (2012): Bromus sitchensis - neu für Österreich, Plantago coronopus - neu für Oberösterreich sowie weitere Beiträge zur Kenntnis der Flora des Innviertels. - Stapfia 97: 180-192.

Horvatić, S. and Gospodarić, L. (1960): Sporobolus vaginaeflorus (Torr.) Wood. u biljnom pokrovu Hrvatske. [The occurrence of Sporobolus vaginaeflorus (Torr.) Wood. in Croatia]. - Acta Bot. Croatica 18/19: 79-103.

HüGIN, G., MAZOMEIT, J. and WolfF, P. (1995): Geranium purpureum - ein weit verbreiteter Neophyt auf Eisenbahnschotter in Südwestdeutschland. - Floristische Rundbriefe 29: 37-41.

JogAn, N. (ed.) (2001): Gradivo za Atlas flore Slovenije. [Materials for the Atlas of Flora of Slovenia]. - Center za kartografijo favne in flore, Miklavž na Dravskem polju, 443 pp.

Kalwij, J. M., Milton, S. J. and McGeoch, M. A. (2008): Road verges as invasion corridors? A spatial hierarchical test in an arid ecosystem. - Landscape Ecol. 23: 439-451.

KiráLY, G. (ed.) (2009): Új magyar füvészkönyv. (New Hungarian herbal). - Aggteleki Nemzeti Park Igazgatóság, Jósvafo, 616 pp.

KowARIK, I. and VON DER LIPPE, M. (2011): Secondary wind dispersal enhances long-distance dispersal of an invasive species in urban road corridors. - Neobiota 9: 49-70. http://dx.doi.org/10.3897/neobiota.9.1469

Melzer, H. (2003): Sporobolus vaginiflorus (Poaceae), ein Neubürger aus Nordamerika, lange übersehen in Österreich - und anderes Neue zur Flora von Kärnten. - Neilreichia 2-3: 131-142.

Niklfeld, H. (1971): Bericht über die Kartierung der Flora Mitteleuropas. - Taxon 20: 545-571. http://dx.doi.org/10.2307/1218258 
Peterson, P. M., Hatch, S. L. and Weakley, A. S. (2007): Sporobolus R. Br. - In: Barkworth, M. E., Anderton, L. A., Capels, K. M., Long, S. and Piep, M. B. (eds): Manual of grasses for North America. Intermountain Herbarium and Utah State University Press, Logan, Utah, pp. 212-217.

Peterson, P. M., Romaschenko, K. and Johnson, G. (2010): A classification of the Chloridoideae (Poaceae) based on multigene phylogenetic trees. - Mol. Phyl. Evol. 55: 580-598. http://dx.doi.org/10.1016/j.ympev.2010.01.018.

PolgáR, S. (1941): Győrmegye flórája. [Flora Comitatus Jaurinensis]. - Bot. Közlem. 38: 201-352.

ŠERÁ, B. (2008): Road vegetation in Central Europe - an example from the Czech Republic. - Biologia 63: 1085-1088. http://dx.doi.org/10.2478/s11756-008-0152-6

STEŠEVIĆ, D. and Jogan, N. (2006): Two new neophytes in the flora of Montenegro: Artemisia verlotiorum and Sporobolus vaginiflorus. - Natura Montenegrina 5: 173-175.

Stöhr, O., Pilsl, P., Essl, F., Wittmann, H. and Hohla, M. (2009): Beiträge zur Flora von Österreich III. - Linzer biol. Beitr. 41: 1677-1755.

ThIERs, B. M. (2015): Index Herbariorum: A global directory of public herbaria and associated staff. - New York Botanical Garden's Virtual Herbarium. http://sweetgum.nybg.org/ih/ [accessed on 15 September 2015]

Tinner, U. (2013): Zwei neue Grasarten im St. Galler Rheintal: Sporobolus vaginiflorus und Sporobolus neglectus. - Baubinia 24: 53-56.

WALTER, J. (1998): Dispersal of Geranium purpureum along railways in Switzerland, Germany and Austria. - Bull. Geobot. Inst. ETH 65: 95.

Wilhalm, T. (1998): Neues zur Ausbreitung von Sporobolus vaginiflorus (Torrey) Wood. - Floristische Rundbriefe 32: 95-100.

(submitted: 14.10 .2015 , accepted: 10.11.2015) 